\title{
The Triatomines of Northern Peru, with Emphasis on the Ecology and Infection by Trypanosomes of Rhodnius ecuadoriensis (Triatominae)
}

\author{
César ACuba Cuba/*, Fernando Abad-Franch"/**;,Judith Roldán Rodríguez $* * * *$, \\ Franklin Vargas Vásquez ${ }^{* * * *}$, Luis Pollack Velásquez ${ }^{* * * * *}$, Michael A Miles*/+
}

\begin{abstract}
Unidade de Parasitologia Médica-Patologia, Faculdade de Medicina, Universidade de Brasília, Brasília, DF, Brasil *Pathogen Molecular Biology and Biochemistry Unit, Department of Infectious and Tropical Diseases, London School of Hygiene and Tropical Medicine, Keppel St., London WC1E 7HT, UK **Unidad de Medicina Tropical, Instituto 'Juan César García',

Quito, Ecuador ***Departamento de Microbiología y Parasitología, Universidad Nacional de Trujillo, Trujillo, Perú
\end{abstract}

Information on the distribution and synanthropic behaviour of triatomines is essential for Chagas disease vector control. This work summarises such information from northern Peru, and presents new data on Rhodnius ecuadoriensis - an important local vector infesting 10-35\% of dwellings in some zones. Three species are strongly synanthropic and may be suitable targets for chemical control of domestic/peridomestic bug populations. Panstrongylus herreri, the main domestic vector in the area, is probably present in sylvatic ecotopes in the Marañon river system. R. ecuadoriensis and Triatoma dimidiata seem exclusively domestic; biogeographical and ecological data suggest they might have spread in association with humans in northern Peru. Confirmation of this hypothesis would result in a local eradication strategy being recommended. Presence of trypanosome natural infection was assessed in $257 \mathrm{R}$. ecuadoriensis; Trypanosoma rangeli was detected in $4 \%$ of bugs. Six further triatomine species are potential disease vectors in the region (T. carrioni, P. chinai, P. rufotuberculatus, P. geniculatus, R. pictipes, and R. robustus), whilst Eratyrus mucronatus, E. cuspidatus, Cavernicola pilosa, Hermanlentia matsunoi, and Belminus peruvianus have little or no epidemiological significance. A strong community-based entomological surveillance system and collaboration with Ecuadorian public health authorities and researchers are recommended.

Key words: Triatominae - ecology - Chagas disease - Rhodnius ecuadoriensis - Trypanosoma rangeli - Trypanosoma cruzi - Peru

Triatomine bugs transmit Trypanosoma cruzi, the causative agent of Chagas disease (Miles 1998). It is estimated that around 650,000-680,000 people might be infected by T. cruzi in Peru, with 5 to 6.8 million people living at risk. These epidemiological data largely refer to southern Peru, where Triatoma infestans is the primary vector (WHO 1991, Barreda 1996, Dias \& Schofield 1999, Guhl 1999). Control activities do not incorporate the northern provinces (where T. infestans is absent), partially because of lacking updated epidemiological and entomological information. Although no representative serological data are available, prevalence may be estimated as $1 \%$ to $2 \%(67,000-134,000$ people), with about $20 \%$ of the population living at risk ( 1.34 million people), based on estimations for the whole country presented by Guhl (1999) (prevalence 2.5\%, and $25 \%$ of the population at risk). Sixteen triatomine species have been reported from the area, 13 of which can be naturally infected by T. cruzi (Lent \& Wygodzinsky 1979,

Supported by Capes (Ministério de Educação e Cultura, Brasil), the Oficina Nacional de Epidemiología and the Instituto Nacional de Salud (Ministerio de Salud Pública, Perú). Additional funding was received from TDR (grant 970195), the ECLAT Network and the Cañada-Blanch Foundation (Spain).

${ }^{+}$Corresponding author. Fax: +44-207-636.8739. E-mail: michael.miles@1shtm.ac.uk

Received 21 May 2001

Accepted 16 August 2001
Calderón et al. 1985, Guillén et al. 1989, Carcavallo et al. 1999a, and this report). T. dimidiata, Panstrongylus herreri, and Rhodnius ecuadoriensis are well adapted to indoors breeding, and are considered significant disease vectors. T. carrioni, $P$. chinai, and $P$. rufotuberculatus also breed inside houses in particular areas of Ecuador, Peru and Bolivia. P. geniculatus can colonise peridomestic pigsties in the Brazilian Amazon and has been found in houses in Colombia and Venezuela. $R$. robustus and $R$. pictipes are sporadic vectors of human disease in the Amazon, where adult bugs frequently invade homes; only very seldom have domestic colonies of $R$. pictipes been reported. Eratyrus mucronatus, E. cuspidatus, Cavernicola pilosa, and T. nigromaculata have little or no epidemiological significance (Lent \& Wygodzinsky 1979, Miles et al. 1981, 1983, Barrett 1991, Noireau et al. 1994, 1995, Sherlock et al. 1997, Carcavallo et al. 1998b, Valente et al. 1998, 1999, Angulo et al. 1999, Reyes-Lugo \& Rodríguez-Acosta 2000, Abad-Franch et al. 2001, Teixeira et al. 2001). Additionally, Rhodnius species act as vectors of T. rangeli (Sherlock et al. 1997, Cuba Cuba 1998, Miles 1998). Here we review the main biogeographical traits of these triatomines in northern Peru, and present new data from field research on $R$. ecuadoriensis. The role of $P$. herreri, $T$. dimidiata, and $P$. chinai as actual or potential disease vectors is also emphasised.

\section{MATERIALS AND METHODS}

Study area - Peru is divided into three main physiographical areas: the coastal region, the mountain- 
ous Andean region, and the Amazonian region. In northern Peru, the Andes split into three branches (eastern, central, and western; this latter separates the Pacific and Amazon slopes). There is a complex pattern of temperate valleys with rivers flowing towards either the Pacific or Amazon slopes. The northern coastal region (0-800 $\mathrm{m}$ altitude) presents a dry climate with xerophytic areas and valleys where permanent rivers allow the growth of thick, evergreen vegetation, and various crops. The northern Andean region (800-4,947 m altitude) includes the highlands, the valleys of rivers flowing into the Pacific Ocean, and the upper stretches of some tributaries of the Amazon. The climate is arid-semiarid, with various cactus species and without palm trees. The Amazon region includes plains covered by dense rain forests, the eastern Andean humid foothills and valleys, and the eastern branch of the Andes ("selva alta"). Eight political constituencies ("Departamentos") comprise the area of interest of the present study: Tumbes, Piura, Lambayeque, La Libertad, Cajamarca (western slope, although some rivers flow into the Amazon), Amazonas, San Martín, and Loreto (eastern slope and Amazon basin). Some 6.7 million people ( $25 \%$ of Peruvian population) live in the area $\left(558,000 \mathrm{~km}^{2}, 43 \%\right.$ of Peru).

Collection of data - Available published reports and the following sources of data were reviewed: (i) the entomological collection, National Institute of Health, Lima, Peru; (ii) the reference collections at Fiocruz, Rio de Janeiro, Brazil; and (iii) records from the Ministry of Health, Lima, Peru - including unpublished reports by the Division of Epidemiology. Our fieldwork records and observations complemented these data. Biogeographical information was obtained from Brack (1987) and Mostacero et al. (1996). Life zone classification was carried out after Curto de Casas et al. (1999).

Entomological surveys - Surveys were carried out in 21 rural localities of Cascas district, La Libertad. A representative sample of dwellings was randomly selected (expected infestation $2.5 \%$, confidence level $95 \%$ ), and 259 domiciliary units (DUs: domiciles+peridomiciles) were inspected (man-hour method). Live or dead triatomines, exuviae, eggs, or faeces, were considered to indicate infestation. A longitudinal, 2-year entomological survey is also being carried out in other rural areas of La Libertad and Cajamarca, using both active and passive methods to detect DU infestation (detailed results will be presented elsewhere). Natural infection of $R$. ecuadoriensis was assessed in haemolymph, salivary glands, and intestinal contents of bugs; parasites were isolated and identified after Cuba Cuba (1998).

\section{RESULTS}

The records of triatomine species from northern Peru are summarised in Tables I and II and in the Figure. Sixteen species were recorded (including a few dubious records discussed below); they occupy 15 different life zones in the region (Table III).

In the Cascas valley (La Libertad), 10 out of 21 (47.6\%) localities surveyed were positive for the presence of $R$. ecuadoriensis; $10 \%$ of dwellings were infested (adults,
TABLE I

Triatominae reported from northern Peru

\begin{tabular}{|c|c|}
\hline Tribe & Species $^{a}$ \\
\hline Bolboderini & $\begin{array}{l}1 \text { Belminus peruvianus Herrer, Lent \& } \\
\text { Wygodzinsky, } 1954\end{array}$ \\
\hline Cavernicolini & 2 Cavernicola pilosa Barber, 1937 \\
\hline Rhodniini & $\begin{array}{l}3 \text { Rhodnius ecuadoriensis Lent \& León, } 1958 \\
4 \text { Rhodnius robustus Larrousse, } 1927 \\
5 \text { Rhodnius pictipes Stål, } 1872\end{array}$ \\
\hline Triatomini & $\begin{array}{l}6 \text { Eratyrus cuspidatus Stål, } 1859 \\
7 \text { Eratyrus mucronatus Stål, } 1859 \\
8 \text { Hermanlentia matsunoi (Fernández-Loayza, } \\
\text { 1989) } \\
9 \text { Panstrongylus chinai (Del Ponte, 1929) } \\
10 \text { Panstrongylus geniculatus (Latreille, 1811) } \\
11 \text { Panstrongylus herreri Wygodzinsky, 1984 } \\
12 \text { Panstrongylus rufotuberculatus } \\
\quad \text { (Champion, 1899) } \\
13 \text { Triatoma carrioni Larrousse, } 1926 \\
14 \text { Triatoma dimidiata (Latreille, 1811) } \\
15 \text { Triatoma nigromaculata (Stål, 1872) } \\
\text { (see text) }\end{array}$ \\
\hline
\end{tabular}

$a$ : numbers used in the map for species distribution; Panstrongylus lignarius not included (see text).

nymphs, eggs, and exuviae found indoors; no peridomestic colonies were detected after systematic searches in chicken coops and corrals). There were 204 insects collected (0.8/house surveyed, 7.8/infested house), mainly from houses with non-plastered walls of adobe or "quinchas" (mud/cane) and thatched or cane-and-clay roofs. Beds made of cane were frequently infested. When active and passive methods to detect infestation were combined, overall infestation rate increased to $\sim 35 \%$, and both intra- and peridomestic $R$. ecuadoriensis colonies were detected (preliminary results from the ongoing, 2year longitudinal survey; authors, unpublished data). $R$. ecuadoriensis was only found in arid environments, and at altitudes up to $2,700 \mathrm{~m}$ - the highest value for the species. Bugs infected by $T$. rangeli were collected in two domiciles only, where 19\% (10/53) insects were infected; salivary gland infection was confirmed in four bugs (7.5\%). Overall T. rangeli infection index was 4\% (10/257).

$P$. chinai is predominantly sylvatic in the study area. Peridomestic colonies were detected in stone wall goat enclosures and among clay blocks; nymphs camouflage by covering themselves with dust. Adult males invade synanthropic habitats; they were frequently captured in the main square of the town of Cascas, apparently attracted to artificial light. Domestic colonies were detected in Piura, nearby the Ecuadorian border.

Although updated information is scarce, the main animal reservoirs of $T$. cruzi in the area seem to be marsupials (Didelphis spp.), rodents (Rattus spp., Cavia porcellus), and, in the Amazon region, primates and bats (cf. Calderón et al. 1985, Jara et al. 1998). 
TABLE II

Biogeography of triatomine species reported from northern Peru

\begin{tabular}{|c|c|c|c|}
\hline Species & Geography ${ }^{c}$ & Valleys & Biology, natural infection \\
\hline Triatoma dimidiata $^{a}$ & $\begin{array}{l}\text { Tumbes: Tumbes, Zarumilla } \\
\text { La Libertad: Pacasmayo }\end{array}$ & $\begin{array}{l}\text { Tumbes, Zarumilla } \\
\text { Chamán }\end{array}$ & $\begin{array}{l}\text { Domestic-peridomestic } \\
\text { Domestic-peridomestic }\end{array}$ \\
\hline Triatoma carrioni ${ }^{a, b}$ & $\begin{array}{l}\text { Piura: Huancabamba (E), Ayabaca (W) } \\
\text { Cajamarca: Jaén, Santa Cruz, } \\
\text { San Miguel, Cutervo, Chota }\end{array}$ & $\begin{array}{l}\text { Huancabamba, Quiroz } \\
\text { Nd }\end{array}$ & $\begin{array}{l}\text { Domestic-peridomestic } \\
\text { Domestic-peridomestic; } \\
\text { Tc (Jaén) }\end{array}$ \\
\hline Triatoma nigromaculata ${ }^{b}$ & San Martín: Lamas (see text) & Mayo & Domestic \\
\hline Hermanlentia matsunoi $^{b}$ & La Libertad: Pataz & Upper Marañón & Sylvatic (caves) \\
\hline Cavernicola pilosa $^{b}$ & Loreto: Iquitos, Francisco de Orellana & Amazon basin & Sylvatic, hollow trees with bats \\
\hline Eratyrus mucronatus ${ }^{b}$ & $\begin{array}{l}\text { San Martín: Huallaga } \\
\text { Loreto: Coronel Portillo }\end{array}$ & $\begin{array}{l}\text { Huallaga } \\
\text { Marañón system }\end{array}$ & $\begin{array}{l}\text { Sylvatic } \\
\text { Sylvatic }\end{array}$ \\
\hline Eratyrus cuspidatus $^{a}$ & $\begin{array}{l}\text { Tumbes: Zarumilla } \\
\text { Piura: Ayabaca }\end{array}$ & $\begin{array}{l}\text { Tumbes, Zarumilla } \\
\text { Nd }\end{array}$ & $\begin{array}{l}\text { Sylvatic } \\
\mathrm{Nd}\end{array}$ \\
\hline Belminus peruvianus ${ }^{b}$ & $\begin{array}{l}\text { Cajamarca: Jaén } \\
\text { Amazonas }\end{array}$ & $\begin{array}{l}\text { Upper Marañón } \\
\text { Marañón }\end{array}$ & $\begin{array}{l}\text { Peridomestic colonies reported } \\
\text { Sylvatic }\end{array}$ \\
\hline Rhodnius ecuadoriensis ${ }^{a, b}$ & $\begin{array}{l}\text { Tumbes: Tumbes, Zarumilla } \\
\text { Piura: Ayabaca, Huancabamba, } \\
\text { Morropón, Piura } \\
\text { Lambayeque: Ferreñafe, Lambayeque } \\
\text { Cajamarca: Jaén, Cutervo, Chota, San } \\
\text { Miguel, Celendín, Cajamarca, } \\
\text { Contumazá, San Benito } \\
\text { La Libertad: Trujillo, Otuzco, Cascas }\end{array}$ & $\begin{array}{l}\text { Tumbes, Zarumilla } \\
\text { Huancabamba, } \\
\text { Huarmaca, Piura } \\
\text { Zaña } \\
\text { Cascas, Santa Ana }\end{array}$ & $\begin{array}{l}\text { Domestic; } T c \\
\text { Domestic-peridomestic } \\
\text { (Schinus molle tree holes); } T c, T r \\
\text { Peridomestic; } T c \\
\text { Domestic-peridomestic; } T r\end{array}$ \\
\hline Rhodnius robustus ${ }^{b}$ & $\begin{array}{l}\text { San Martín } \\
\text { Loreto: Coronel Portillo }\end{array}$ & $\begin{array}{l}\text { Huallaga } \\
\text { Yarinacocha, Ucayali }\end{array}$ & $\begin{array}{l}\text { Sylvatic (palms); } T c \\
\text { Sylvatic (palms) }\end{array}$ \\
\hline Rhodnius pictipes ${ }^{b}$ & $\begin{array}{l}\text { Loreto: Coronel Portillo } \\
\text { San Martín }\end{array}$ & $\begin{array}{l}\text { Yurimaguas, Callerías, } \\
\text { Yarinacocha } \\
\text { Huallaga valley } \\
\text { (Huallobamba) }\end{array}$ & $\begin{array}{l}\text { Sylvatic (palms); } T c \\
\text { Domestic colonies claimed }\end{array}$ \\
\hline Panstrongylus herreri ${ }^{b},(a ?)$ & $\begin{array}{l}\text { San Martín: Moyobamba, Rioja } \\
\text { Amazonas: Bagua, Rodríguez de } \\
\text { Mendoza } \\
\text { Cajamarca: Jaén, Cutervo, } \\
\text { San Ignacio, Santa Cruz } \\
\text { Piura: Ayabaca }\end{array}$ & $\begin{array}{l}\text { Marañón, Huallaga } \\
\text { Marañón } \\
\text { Marañón, Huallaga } \\
\text { Nd }\end{array}$ & $\begin{array}{l}\text { Domestic; } T c \\
\text { Domestic } \\
\text { Domestic; } T c \\
\text { Peridomestic }\end{array}$ \\
\hline Panstrongylus chinai ${ }^{a, b}$ & $\begin{array}{l}\text { Piura: Huancabamba, Ayabaca, Morropón, } \\
\text { Paita, Piura, Sullana, Talara } \\
\text { Tumbes: Zarumilla, Tumbes, } \\
\text { Comandante Villar } \\
\text { Lambayeque: Lambayeque } \\
\text { La Libertad: Trujillo, Huamacucho, } \\
\text { Otuzco, Bolívar, Chepén } \\
\text { Cajamarca: Cajamarca, Contumazá, } \\
\text { Celendín, Santa Cruz } \\
\text { Amazonas: Bagua, Rodríguez de } \\
\text { Mendoza, Chachapoyas }\end{array}$ & $\begin{array}{l}\text { Huancabamba, Chira } \\
\text { Zarumilla, Tumbes } \\
\text { Zaña } \\
\text { Chamán } \\
\text { Inter-Andean and } \\
\text { transversal valleys } \\
\text { Amazon basin }\end{array}$ & $\begin{array}{l}\text { Peridomestic; domestic; } T c \\
\text { Peridomestic; } T c \\
\text { Peridomestic; } T c \\
\text { Peridomestic; } T c \\
\text { Peridomestic; sylvatic } \\
\text { (attracted to light); } T c \\
\text { Peridomestic; sylvatic }\end{array}$ \\
\hline Panstrongylus geniculatus $b$ & $\begin{array}{l}\text { Cajamarca: Jaén, San Ignacio, Cutervo } \\
\text { Loreto: Coronel Portillo }\end{array}$ & $\begin{array}{l}\mathrm{Nd} \\
\text { Amazon basin }\end{array}$ & $\begin{array}{l}\text { Sylvatic; } T c \\
\text { Sylvatic; } T c\end{array}$ \\
\hline $\begin{array}{l}\text { Panstrongylus } \\
\text { rufotuberculatus }\end{array}$ & $\begin{array}{l}\text { Tumbes: Comandante Villar } \\
\text { Piura: Ayabaca }\end{array}$ & $\begin{array}{l}\text { Tumbes } \\
\mathrm{Nd}\end{array}$ & $\begin{array}{l}\text { Sylvatic; peridomestic } \\
\mathrm{Nd}\end{array}$ \\
\hline Panstrongylus lignarius $b$ & San Martín (see text) & Amazon basin & Sylvatic \\
\hline
\end{tabular}

$\bar{a}$ : reported from the Pacific slope; $b$ : reported from the Amazon slope; $c$ : Departments: provinces; Tc: Trypanosoma cruzi; Tr: Trypanosoma rangeli; Nd: no specific data. Additional information was obtained from Herrer and Wygodzinsky (1954), Herrer (1956, 1959, 1977), and Fernández-Loayza (1989). 


\section{DISCUSSION}

T. dimidiata, P. herreri, and $R$. ecuadoriensis are strongly synanthropic in northern Peru, and six more species can invade and sometimes colonise houses or peridomestic structures. Three of them may act as secondary disease vectors (T. carrioni, P. chinai, and $P$. rufotuberculatus), and $R$. pictipes, $R$. robustus and $P$. geniculatus may also be of some importance. Our study area comprised 15 life zones (including desert coastal lowlands, temperate Andean valleys, and humid forests). Some triatomines may have spread following these valleys, and have reached areas that appear out of their usual range.

Triatomine species

$P$. herrer $i$ is considered the principal vector of Chagas disease in northern Peru. Its distribution includes 5 Departments and 11 provinces, and it may be found at alti- tudes up to $1,500 \mathrm{~m}$. It preferentially occupies humid life zones, and it is domestic-peridomestic in our study area (Herrer 1955, Lent \& Wygodzinsky 1979, Calderón et al. 1985, Carcavallo et al. 1998b, 1999a, Curto de Casas et al. 1999). The species was recently reported from Ecuador (Aguilar et al. 1999). P. herreri shares most of its external characters with $P$. lignarius, a sylvatic Amazonian triatomine (see Lent \& Wygodzinsky 1979). The only record of P. lignarius from Peru (cf. Calderón et al. 1985) may be due to misidentification; however, the taxonomic status of these two species remains unclear (Carcavallo et al. 1999b).

T. dimidiata is strongly synanthropic in northern Peru and in coastal Ecuador, where it is an important Chagas disease vector (Lent \& Wygodzinsky 1979, Lazo 1985, Schofield 1994, Aguilar et al. 1999). In Peru, the species seems restricted to low, dry areas of Tumbes and La Libertad (its distribution being discrete rather than con-

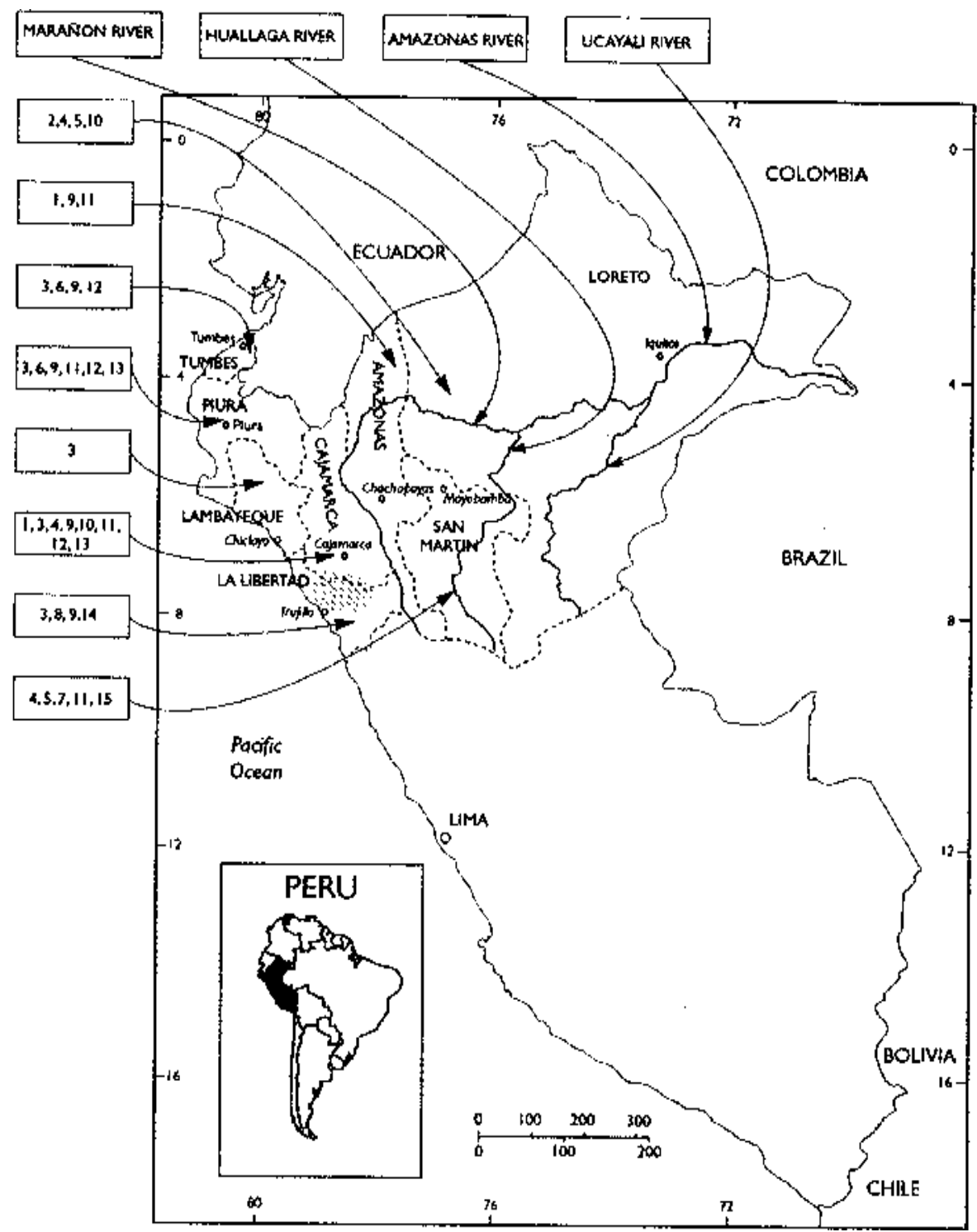

Departments of northern Peru; numbers in boxes indicate the species of Triatominae reported from each Department (numbers as in Table I). The area where field studies on Rhodnius ecuadoriensis were conducted is marked with diagonal lines. 
TABLE III

Triatomines from northern Peru: life zone ecology

\begin{tabular}{|c|c|c|c|c|}
\hline Life zones ${ }^{a}$ & Annual rain (mm) & Temperature $\left({ }^{\circ} \mathrm{C}\right)$ & Altitude (m) & Species \\
\hline Tropical desert & $0-125$ & $29-30$ & $0-125$ & $\begin{array}{l}\text { T. dimidiata } \\
\text { R. ecuadoriensis } \\
\text { P. chinai }\end{array}$ \\
\hline Premontane desert & $0-125$ & $15-16.5$ & $2250-2500$ & P. chinai \\
\hline Tropical desert scrub & $125-250$ & $28.5-29$ & $125-250$ & $\begin{array}{l}\text { T. dimidiata } \\
\text { R. ecuadoriensis } \\
\text { P. chinai } \\
\text { P. geniculatus }\end{array}$ \\
\hline Premontane desert scrub & $125-250$ & $16.5-18$ & $2000-2250$ & R. ecuadoriensis \\
\hline Tropical thorn scrub & $250-500$ & $28-28.5$ & $250-375$ & $\begin{array}{l}\text { T. dimidiata } \\
\text { R. ecuadoriensis } \\
\text { P. chinai } \\
\text { P. rufotuberculatus }\end{array}$ \\
\hline Premontane thorn scrub & $250-500$ & $18-19.5$ & $1750-2000$ & $\begin{array}{l}\text { P. chinai } \\
\text { E. mucronatus }\end{array}$ \\
\hline Very dry tropical forest & $500-1000$ & $27-28$ & $375-500$ & $\begin{array}{l}\text { T. dimidiata } \\
\text { R. ecuadoriensis } \\
\text { E. mucronatus }\end{array}$ \\
\hline Dry tropical forest & $1000-2000$ & $26-27$ & $500-625$ & $\begin{array}{l}\text { T. dimidiata } \\
\text { R. ecuadoriensis } \\
\text { P. rufotuberculatus } \\
\text { P. geniculatus } \\
\text { E. cuspidatus } \\
\text { E. mucronatus }\end{array}$ \\
\hline Dry premontane forest & $500-1000$ & $19.5-21$ & $1500-1750$ & $\begin{array}{l}\text { T. carrioni } \\
\text { R. ecuadoriensis } \\
\text { P. rufotuberculatus } \\
\text { E. mucronatus }\end{array}$ \\
\hline Tropical wet forest & $2000-4000$ & $25.5-26$ & $625-750$ & $\begin{array}{l}\text { R. pictipes } \\
\text { T. nigromaculata (?) } \\
\text { R. robustus } \\
\text { P. herreri } \\
\text { P. geniculatus } \\
\text { E. cuspidatus } \\
\text { E. mucronatus } \\
\text { C. pilosa }\end{array}$ \\
\hline Premontane wet forest & $1000-2000$ & $21-22.5$ & $1250-1500$ & $\begin{array}{l}\text { T. carrioni } \\
\text { P. herreri } \\
\text { P. rufotuberculatus } \\
\text { E. cuspidatus } \\
\text { E. mucronatus } \\
\text { H. matsunoi }\end{array}$ \\
\hline Tropical moist forest & $4000-8000$ & $25-25.5$ & $750-875$ & P. rufotuberculatus \\
\hline Premontane moist forest & $2000-4000$ & $22.5-24$ & $1000-1250$ & $\begin{array}{l}\text { T. carrioni } \\
\text { P. rufotuberculatus } \\
\text { P. geniculatus } \\
\text { B. peruvianus }\end{array}$ \\
\hline Tropical pluvial forest & $>8000$ & $24-25$ & $875-1000$ & $\begin{array}{l}R . \text { robustus } \\
B . \text { peruvianus }\end{array}$ \\
\hline Low montane desert scrub & $250-500$ & $13.5-15$ & $2500-2750$ & T. carrioni \\
\hline
\end{tabular}

a: life zones based on Curto de Casas et al. (1999); T.: Triatoma; R.: Rhodnius; P.: Panstrongylus; E.: Eratyrus; B.: Belminus; C.: Cavernicola; H.: Hermanlentia 
tinuous) (Lizaraso 1955, Hidalgo 1957, Jara et al. 1998). Sylvatic populations have not been documented in Peru or Ecuador (cf. Abad-Franch et al. 2001). These features, and the discontinuity of the distribution of $T$. dimidiata in southern Colombia (only reported from the upper Magdalena valley) (Zeledón 1981, D’ Alessandro \& Barreto 1985), could be explained by an artificial introduction of the species to Ecuador and Peru. Preliminary results of morphometric (Abad-Franch 2000) and molecular studies (Marcilla et al. 2001) are lending support to this hypothesis. If confirmed, this would imply that eradication of the species from the region might be attainable (see Schofield 2000).

$R$. ecuadoriensis is a significant disease vector in southern Ecuador and northern Peru (Lent \& Wygodzinsky 1979, Schofield 1994, Aguilar et al. 1999); even so, the studies on its ecology, behaviour, or vectorial role, are scarce and limited. It was first reported from Peru in 1955 (Llanos 1961, Herrer et al. 1972). Cuba Cuba et al. (1972) described domestic colonies in Cajamarca (7\% infected by $T$. rangeli). F Vargas V (unpubl.) found $25 \%$ of 463 specimens infected by $T$. rangeli in La Libertad, and Castillo (1995) reported peridomestic colonies of the species from the Zaña valley, Lambayeque. Calderón (1996) reported that $3 \%$ of 3,450 triatomines captured in Tumbes and Piura (1973-1981) were R. ecuadoriensis. Sylvatic populations of this species occupy Phytelephas aequatorialis palm trees (endemic to humid areas of western Ecuador) (Borchsenius et al. 1998, Abad-Franch et al. 2000, 2001). Other ecotopes recorded are Elaeis guineensis, an artificially introduced, cultivated African palm (infested in Los Ríos, Ecuador, although only eggs and adults were found - the absence of nymphs perhaps indicating failure to colonise the ecotope; see Carcavallo \& Martínez 1985), and a single record of the species in a hollow tree in an allegedly uninhabited area (Herrer et al. 1972); its presence in cacti has been cited (cf. Barrett 1991) but probably represents temporary occupation of the nest of a vertebrate near to an infested dwelling. Palm trees, the true primary habitat of the species, are absent from the arid-semiarid areas where $R$. ecuadoriensis is strongly synanthropic. The only documented finding of the species in an uninhabited area of Peru refers to a single nymph collected from a Schinus molle hollow tree. These observations suggest that $R$. ecuadoriensis probably has no truly sylvatic ecotope in northern Peru, and that its presence in the region is probably related to passive transportation in association with humans (perhaps about the early 1950 s, as it was never reported before from Peru). The occurrence of the species within houses at high altitudes and in very arid zones also suggests a close bug-human association. Such a hypothesis would be rejected if truly sylvatic colonies were satisfactorily documented, and is currently being tested by means of morphometric and molecular analyses using different bug populations. If the hypothesis were not rejected, this would mean that a local eradication strategy could be implemented in northern Peru and some areas of Ecuador with good chances of success.

Our results show a moderately high house infestation rate $(10 \%)$, with small breeding colonies inside houses rather than in peridomiciles. However, an overall infesta- tion rate of $35 \%$ was revealed by a 2 -year longitudinal survey in La Libertad (authors, unpubl.). The studied localities are located in arid valleys of the western slope of the Andes. Available data agree in that domesticperidomestic populations of R. ecuadoriensis can be found in similar valleys throughout north-western Peru, suggesting that they constitute a favourable biotope for the species; however, further studies are required to accurately define the biogeography of the species in the country.

Natural infection by $T$. cruzi was absent in $257 R$. ecuadoriensis examined, whereas $T$. rangeli was detected in $4 \%$ of bugs, suggesting that diagnostic tests for $T$. cruzi might yield false-positive results in some cases (Cuba Cuba 1998). This finding does not preclude however that T. cruzi may be transmitted by this species (e.g. Llanos 1961, Herrer et al. 1972, Lazo 1985, Castillo 1995).

$P$. chinai occurs on both slopes of the Andes in northern Peru and southern Ecuador. Although mainly sylvatic, its ability to invade and occasionally colonise DUs has been documented (Lent \& Wygodzinsky 1979, Calderón et al. 1985, Lazo 1985). The species transmits T. cruzi among rats (Rattus norvegicus) and marsupials (Didelphis spp.) in Peru, and infected $P$. chinai nymphs were found in peridomestic ecotopes in La Libertad (Jara et al. 1998). The species is to be considered as a potential secondary vector in its distribution areas. Despite the claims that the species can be found in Venezuela (cf. Carcavallo et al. 1998a), we deem that it is most likely endemic to arid areas of northern Peru-southern Ecuador; those reports may be due to erroneous labelling of specimens or misidentification, and have led to concern that the species might be widespread in the Amazon and present in Colombia (Molina et al. 2000).

T. carrioni occasionally colonises human habitats in southern Ecuador and northern Peru. It occurs in both dry and humid life zones up to 2,650 m altitude (Lumbreras et al. 1955, Lent \& Wygodzinsky 1979, Defranc 1982, Lazo 1985). In southern Ecuador, T. carrioni was considered an important pest until it was apparently replaced by $R$. ecuadoriensis (already present in the area in 1958, when the species was described from domestic bugs from La Toma, Loja) (Lent \& León 1958, Defranc 1982, Lazo 1985). The presence of wild populations indicates that the possibility of re-infestation of treated dwellings persists.

$P$. rufotuberculatus is domestic in some areas of Peru, Ecuador, and Bolivia (Lizaraso 1955, Calderón et al. 1985, Lazo 1985, Noireau et al. 1994, Dujardin et al. 1998, AbadFranch et al. 2001). Its epidemiological role deserves further research, at least in the Andean valleys and foothills where it seems adapted to human habitats. The species occurs mainly in low, dry areas, but may also be found in humid forests (and in higher valleys in southern Peru).

$P$. geniculatus occurs mainly in the Amazonian rainforests of Loreto, but has also been collected in Cajamarca (Lumbreras 1972). This is largely a sylvatic species, but seems to be readily attracted to electric light and occasionally colonises peridomestic pigsties and domiciles (Valente et al. 1998, Angulo et al. 1999, Reyes-Lugo \& Rodríguez-Acosta 2000).

$R$. pictipes and $R$. robustus are reported from a wide geographical range in the Amazon. Records from 
Cajamarca (Lumbreras 1972) and Trujillo (Fiocruz collections) are probably due to labelling errors. The biological characteristics of these sylvatic, palm tree-living Amazonian triatomines make us believe that adaptation to dry highlands with no palms, and thus their presence on the western slope of the Andes, is unlikely.

Other species (E. mucronatus, E. cuspidatus, Belminus peruvianus, Hermanlentia matsunoi, and C. pilosa) have little or no epidemiological significance in Peru. E. cuspidatus and E. mucronatus have been reported to show some degree of synanthropism in different countries (Lent \& Wygodzinsky 1979, Noireau et al. 1995) but are still mainly sylvatic.

The presence of T. nigromaculata in Peru has been reported once (Calderón \& Monzón 1995). Previously, the species was only known from Venezuela, where it is sylvatic (Lent \& Wygodzinsky 1979). The probable affiliation of T. nigromaculata to the dispar complex (including T. dispar, T. venosa, and T. carrioni) may help explain this record. Although the species presents a quite characteristic chromatic pattern, it is conceivable that a pale variety of $T$. carrioni could have been misclassified as $T$. nigromaculata. The record deserves however further investigation.

Finally, it is worth mentioning that the main vector in the south of Peru, $T$. infestans, has never been reported from the area of interest of the present study. From its Bolivian origin, the species reached suburban areas of Lima, probably in association with rural immigrants. However, the migratory movements from the south rarely reach the northern Departments, as there are no higher standards of living in the north. Thus, the likelihood of $T$. infestans being introduced seems low.

The presence of a wide variety of triatomines in northern Peru ( $12 \%$ of all recognised species), many of them occupying wild environments, could represent an important difficulty for disease control in the zone. T. dimidiata, $P$. herreri, and $R$. ecuadoriensis may constitute suitable targets for interventions against synanthropic bug populations, but the presence of other potential vector species (mainly T. carrioni, P. rufotuberculatus and P. chinai, and possibly also $P$. geniculatus, $R$. pictipes, and $R$. robustus - whose role as vectors needs to be clarified) must be taken into account. Some of these autochthonous species may behave as secondary vectors, occupying empty niches after domestic insects are eliminated by insecticide spraying. A strong longitudinal vigilance system with community involvement should be established to complement extensive residual insecticide spraying (Dias \& Schofield 1999, Dias 2000). Finally, the control of vectorborne Chagas disease in the region must be developed on both sides of the Peruvian-Ecuadorian border. Strong collaborative links between public health authorities and research groups from both countries must be actively promoted and encouraged.

\section{REFERENCES}

Abad-Franch F 2000. Ecology and Genetics of Chagas Disease Vectors in Ecuador. Implications for the Design of Control Strategies, MPhil-PhD Upgrading Report, LSHTM, London, $150 \mathrm{pp}$.
Abad-Franch F, Noireau F, Paucar CA, Aguilar VHM, Carpio CC, Racines VJ 2000. The use of live-bait traps for the study of sylvatic Rhodnius populations (Hemiptera: Reduviidae) in palm trees. Trans $R$ Soc Trop Med Hyg 94: 629630.

Abad-Franch F, Paucar CA, Carpio CC, Cuba Cuba CA, Aguilar VHM, Miles MA 2001. Biogeography of Triatominae (Hemiptera: Reduviidae) in Ecuador: implications for the design of control strategies. Mem Inst Oswaldo Cruz 96: 611-620.

Aguilar VHM, Abad-Franch F, Racines VJ, Paucar CA 1999. Epidemiology of Chagas disease in Ecuador. A brief review. Mem Inst Oswaldo Cruz 94 (Suppl. I): 387-393.

Angulo VM, Gutiérrez R, Rubio I, Joya M, Arismendi M, Esteban L, Sandoval CM 1999. Triatomíneos domiciliados y silvestres: impacto en la transmisión de la enfermedad de Chagas en Santander. In VM Angulo, Control y Manejo de la Trypanosomiasis Americana. Curso-taller Internacional, Universidad Industrial de Santander-CINTROP, Bucaramanga, Colombia, p. 72-76.

Barreda G 1996. Enfermedad de Chagas en el Perú. In CJ Schofield, JP Dujardin, J Jurberg (eds), Proceedings of the International Workshop on Population Genetics and Control of Triatominae, Santo Domingo de los Colorados, Ecuador, Sept. 1995, INDRE, Mexico City, Mexico, p. 39.

Barrett TV 1991. Advances in triatomine bug ecology in relation to Chagas disease. Adv Dis Vector Res 8: 143-176.

Borchsenius F, Borgtoft Pedersen H, Balslev H 1998. Manual to the Palms of Ecuador, AAU Reports 37, Aarhus University, Universidad Católica del Ecuador, Aarhus, Denmark, $221 \mathrm{pp}$.

Brack A 1987. Ecología de un país complejo. In MJ Dourojeanni, Gran Geografía del Perú: Naturaleza y Hombre, vol. II, Manfer Juan Mejía Baca, Spain, p. 179-194.

Calderón FGE 1996. Chinches triatominos (Hemiptera: Reduviidae) de la Región Grau, Perú. Rev Peruana Entomol 38 : 19-22.

Calderón FGE, Monzón L 1995. Nota científica: primer hallazgo de Triatoma nigromaculata (Stål, 1872) en el Perú. Rev Peruana Entomol 37: 124.

Calderón FGE, Figueroa K, Náquira F, Carcavallo RU, Canale DM 1985. Perú. In RU Carcavallo, JE Rabinovich, RJ Tonn (eds), Factores Biológicos y Ecológicos de la Enfermedad de Chagas, vol. II, CPEHS OPS/OMS, SNCh, Ministerio de Salud y Acción Social, Argentina, p. 449-456.

Carcavallo RU, Martínez A 1985. Biología, ecología, distribución geográfica de los triatominos americanos. In RU Carcavallo, JE Rabinovich, RJ Tonn (eds), Factores Biológicos y Ecológicos en la Enfermedad de Chagas, vol. I, CPEHS OPS/OMS, SNCh, Ministerio de Salud y Acción Social, Argentina, p. 149-208.

Carcavallo RU, Curto de Casas SI, Sherlock IA, Galíndez Girón I, Jurberg J, Galvão C, Mena Segura CA, Noireau F 1999a. Geographical distribution and alti-latitudinal dispersion. In RU Carcavallo, I Galíndez Girón, J Jurberg, H Lent (eds), Atlas of Chagas Disease Vectors in the Americas, vol. III, Fiocruz, Rio de Janeiro, p. 747-792.

Carcavallo RU, Galvão C, Lent H 1998a. Triatoma jurbergi sp. n. do norte do Estado do Mato Grosso, Brasil (Hemiptera, Reduviidae, Triatominae), com uma atualização das sinonímias e outros táxons. Mem Inst Oswaldo Cruz 93: 459-464.

Carcavallo RU, Jurberg J, Lent H 1999b. Phylogeny of the Triatominae. A - General approach. In RU Carcavallo, I Galíndez Girón, J Jurberg, H Lent (eds), Atlas of Chagas Disease Vectors in the Americas, vol. III, Fiocruz, Rio de Janeiro, p. 925-969. 
Carcavallo RU, Rodríguez MEF, Salvatella R, Curto de Casas SI, Sherlock IA, Galvão C, Rocha DS, Galíndez Girón I, Otero Arocha MA, Martínez A, Da Rosa JA, Canale DM, Farr TH, Barata JMS 1998b. Habitats and related fauna. A: General. In RU Carcavallo, I Galíndez Girón, J Jurberg, H Lent (eds), Atlas of Chagas Disease Vectors in the Americas, vol. II, Fiocruz, Rio de Janeiro, p. 561-600.

Castillo RO 1995. Rhodnius ecuadoriensis naturalmente infectado por Trypanosoma cruzi en el valle de Zaña, Lambayeque. II Congreso Peruano de Parasitología, Trujillo, Perú, p. 38.

Cuba Cuba CA 1998. Revisión de los aspectos biológicos y diagnósticos del Trypanosoma (Herpetosoma) rangeli. Rev Soc Bras Med Trop 31: 207-220.

Cuba Cuba CA, Morales N, Fernández E, Fernández W 1972. Hallazgo de Rhodnius ecuadoriensis Lent \& León, 1958 infectado naturalmente por trypanosomas semejantes a Trypanosoma rangeli Tejera, 1920 en caseríos de la Provincia de Cascas, Contumazá, Perú. Rev Inst Med Trop São Paulo 14: 191-202.

Curto de Casas SI, Carcavallo RU, Galíndez Girón I, Burgos JJ 1999. Bioclimatic factors and zones of life. In RU Carcavallo, I Galíndez Girón, J Jurberg, H Lent (eds), Atlas of Chagas Disease Vectors in the Americas, vol. III, Fiocruz, Rio de Janeiro, p. 793-838.

D'Alessandro A, Barreto P 1985. Colombia. In RU Carcavallo, JE Rabinovich, RJ Tonn (eds), Factores Biológicos y Ecológicos de la Enfermedad de Chagas, vol. II, CPEHS OPS/OMS, SNCh, Ministerio de Salud y Acción Social, Argentina, p. 377-399.

Defranc MI 1982. Enfermedad de Chagas, Casa de la Cultura Ecuatoriana, Núcleo del Guayas, Guayaquil, Ecuador, 200 $\mathrm{pp}$.

Dias JCP 2000. Vigilância epidemiológica em doença de Chagas. Cad Saúde Púb 16 (Suppl. 2): 43-59.

Dias JCP, Schofield CJ 1999. The evolution of Chagas disease (American trypanosomiasis) control after 90 years since Carlos Chagas discovery. Mem Inst Oswaldo Cruz 94 (Suppl. I): $103-121$.

Dujardin JP, Forgues G, Torrez M, Martínez E, Córdoba C, Gianella A 1998. Morphometrics of domestic Panstrongylus rufotuberculatus in Bolivia. Ann Trop Med Parasitol 92: 219-228.

Fernández-Loayza R 1989. Triatoma matsunoi, nueva especie del norte peruano (Hemiptera, Reduviidae, Triatominae). Rev Peruana Entomol 31: 21-24.

Guhl F 1999. Programas en la eliminación de la transmisión de la enfermedad de Chagas en los países andinos. In CJ Schofield, C Ponce (eds), Proceedings of the Second International Workshop on Population Genetics and Control of Triatominae, Tegucigalpa, Honduras, March 1998, INDRE, Mexico City, p. 38-43.

Guillén Z, Cáceres I, Elliot A, Ramírez J 1989. Triatominos del norte peruano y su importancia como vectores de Trypanosoma spp. Rev Peruana Entomol 31: 25-30.

Herrer A 1955. Trypanosomiasis Americana en el Perú V. Triatominos del valle interandino del Marañón. Rev Med Exp Lima 9: 69-81.

Herrer A 1956. Observaciones sobre la enfermedad de Chagas en la Provincia de Moyobamba (Departamento de San Martín). Rev Med Exp Lima 10: 59-74.

Herrer A 1959. La enfermedad de Chagas en el Perú: breve revisión de los conocimientos adquiridos hasta 1958. Rev Goiana Med 5: 389-409.

Herrer A 1977. Reseña de la Entomología Médica en el Perú. I. Principales aspectos entomológicos en la bartonelosis, la trypanosomiasis y la leishmaniasis. Rev Peruana Entomol 20: $19-24$.
Herrer A, Wygodzinsky P 1954. Contribución al conocimiento del género Belminus Stål, 1859 (Triatominae, Reduviidae, Hemiptera). An Inst Med Reg Tucumán 4: 85-105.

Herrer A, Wygodzinsky P, Napan M 1972. Presencia de Trypanosoma rangeli Tejera, 1920, en el Perú. I. El insecto vector, Rhodnius ecuadoriensis Lent \& León, 1958. Rev Biol Trop 20: 141-149.

Hidalgo R 1957. Trypanosomiasis Americana en el Perú. Observaciones entomológicas en el Departamento de Tumbes. Rev Med Exp Lima 11: 71-85.

Jara CA, Escalante H, Roldán J, Díaz Limai E 1998. Distribución y frecuencia de infección por Trypanosoma cruzi de triatominos y Ovis aries en el valle de Chamán, La Libertad, Perú. Sciendo 1: 23-31.

Lazo R 1985. Ecuador. In RU Carcavallo, JE Rabinovich, RJ Tonn (eds), Factores Biológicos y Ecológicos de la Enfermedad de Chagas, vol. II, CPEHS OPS/OMS, SNCh, Ministerio de Salud y Acción Social, Argentina, p. 413427.

Lent H, León LA 1958. Um novo Rhodnius Stål do Ecuador (Hemiptera, Reduviidae). Rev Bras Biol 18: 181-185.

Lent H, Wygodzinsky P 1979. Revision of the Triatominae (Hemiptera, Reduviidae), and their significance as vectors of Chagas disease. Bull Am Mus Nat History 163: 123-520.

Lizaraso Y 1955. Nota sobre el hallazgo de Triatoma dimidiata y Panstrongylus rufotuberculatus en el Perú. Rev Med Exp Lima 9: 119-121.

Llanos B 1961. Hallazgo en el Perú del Rhodnius ecuadoriensis Lent \& León, 1958 naturalmente infectado por el Trypanosoma cruzi. Arch Per Patol Clín Lima 15: 133-140.

Lumbreras H 1972. El problema de la enfermedad de Chagas en los Departamentos del Perú. Rev Viernes Méd Lima 23: 4377.

Lumbreras H, Arrarte JA, Tejada A 1955. Nota acerca de la presencia del Panstrongylus herreri y Triatoma carrioni en el distrito de Querocotillo, Provincia de Cutervo del Departamento de Cajamarca. Rev Méd Peruana 26: 444446.

Marcilla A, Bargues MD, Ramsey JM, Magallón-Gastélum E, Salazar-Schettino PM, Abad-Franch F, Dujardin JP, Schofield CJ, Mas-Coma S 2001. The ITS-2 of the nuclear rDNA as a molecular marker for populations, species, and phylogenetic relationships in Triatominae (Hemiptera: Reduviidae), vectors of Chagas disease. Mol Phylogenet Evol 18: 136-142.

Miles MA 1998. New World Trypanosomiasis. In L Collier, A Balows, M Sussman (eds), Microbiology and Microbial Infections, vol. 5: Parasitology, Topley \& Wilson's, UK, p. 238-302.

Miles MA, Arias RJ, Souza AA 1983. Chagas disease in the Amazon basin: V. Periurban palms as habitats of Rhodnius robustus and Rhodnius pictipes - triatomine vectors of Chagas disease. Mem Inst Oswaldo Cruz 78: 391-398.

Miles MA, Souza AA, Povoa M 1981. Chagas disease in the Amazon basin. III. Ecotopes of ten triatomine bugs species (Hemiptera: Reduviidae) from the vicinity of Belém, Pará State, Brazil. J Med Entomol 18: 266-278.

Molina JA, Gualdrón LE, Brochero HL, Olano VA, Barrios D, Guhl F 2000. Distribución actual e importancia epidemiológica de las especies de triatominos (Reduviidae: Triatominae) en Colombia. Biomedica 20: 344-360.

Mostacero LJ, Mejía F, Peláez FP 1996. Fitogeografía del Norte del Perú, Concytec, Lima, Peru.

Noireau F, Bosseno MF, Carrasco R, Telleria J, Vargas F, Camacho C, Yaksic N, Brenière SF 1995. Sylvatic triatomines (Hemiptera: Reduviidae) in Bolivia: trends towards domesticity and possible infection with Trypanosoma cruzi 
(Kineto-plastida: Trypanosomatidae). J Med Entomol 32: 594-598.

Noireau F, Bosseno MF, Vargas F, Brenière SF 1994. Apparent trend to domesticity observed in Panstrongylus rufotuberculatus Champion, 1899 (Hemiptera: Reduviidae) in Bolivia. Res Rev Parasitol 54: 263-264.

Reyes-Lugo M, Rodríguez-Acosta A 2000. Domiciliation of the sylvatic Chagas disease vector Panstrongylus geniculatus Latreille, 1811 (Triatominae: Reduviidae) in Venezuela. Trans $R$ Soc Trop Med Hyg 94: 508.

Schofield CJ 1994. Triatominae. Biología y Control, Eurocommunica Publications, West Sussex, $80 \mathrm{pp}$.

Schofield CJ 2000. Challenges of Chagas Disease Vector Control in Central America, Position paper WHO/CDS/ WHOPES/GCDPPH/2000.1, WHO, Geneva, 36 pp.

Sherlock IA, Carcavallo RU, Galíndez Girón I 1997. List of natural and experimental flagellate infections in several Triatominae species. In RU Carcavallo, I Galíndez Girón, J Jurberg, H Lent (eds), Atlas of Chagas Disease Vectors in the Americas, vol. I, Fiocruz, Rio de Janeiro, p. 289-298. Teixeira ARL, Monteiro PS, Rebelo JM, Argañaraz ER, Vieira D, Lauria-Pires L, Nascimento R, Vexenat CA, Silva AR, Ault SK, Costa JM 2001. Emerging Chagas disease: trophic network and cycle of transmission of Trypanosoma cruzi from palm trees in the Amazon. Emerg Infect Dis 7: 100112.

Valente SAS, Valente VC, Fraiha Neto H 1999. Considerations on the epidemiology of Chagas disease in the Brazilian Amazon. Mem Inst Oswaldo Cruz 94 (Suppl. I): 395-398.

Valente VC, Valente SAS, Noireau F, Carrasco HJ, Miles MA 1998. Chagas disease in the Amazon basin: association of Panstrongylus geniculatus (Hemiptera: Reduviidae) with domestic pigs. J Med Entomol 35: 99-103.

WHO-World Health Organization 1991. Control of Chagas disease, WHO Technical Report, Series 811.

Zeledón R 1981. El Triatoma dimidiata y su Relación con la Enfermedad de Chagas, Universidad Estatal a Distancia, San José, Costa Rica, 146 pp. 
184 The Triatomines of Northern Peru • César A Cuba Cuba et al. 